\title{
Integration Of Quality Science In Improving The Quality Of Legal Education To Globalization
}

\author{
Tarsisius Murwadji \\ Faculty of Law \\ Padjadjaran University \\ Bandung, Indonesia \\ t.murwadji@unpad.ac.id
}

\author{
Bambang Daru Nugroho \\ Faculty of Law \\ Padjadjaran University \\ Bandung, Indonesia \\ bambang.d.nugroho@unpad.ac.id
}

\begin{abstract}
The law holds that quality science is a science for economists and technocrats. This essay argues that the opinion is not appropriate because it is a science that should be learned by all professions that produce products and services, including legal scholars. Current legal problems are largely due to ignorance and reluctance of law scholars to study quality science. According to legal writers, law graduates are not qualified if they do not know quality science. This essay proposes 'Legal Quality Audit', which is the integration of quality science into legal audit system. There are two legal quality audit systems, namely regulatory audits (normative quality audits) and audits of legal implementation (implementation quality audit). If law is based on quality then economic development will be effective, efficient and it will satisfy the society.
\end{abstract}

Keywords - Integration, Quality, Legal Audit, Legal Quality, Legal Audit System

\section{INTRODUCTION}

A few moments ago, there are two high profile legal cases in Indonesia: alleged corruption of Electronic Identity Card and the election widely reported of Regional Representatives Council Republic of Indonesia chairman. The case of Electronic Identity card, in the indictment of the Corruption Eradication Commission Prosecutor, names people from party leaders, former and active members of parliament, and government officials. In the case of the election of the Regional Representatives Council Republic of Indonesia Leadership, we see the push-pushing action and the "dispute" of the representatives of the people.

From these two examples of legal matters, people are stunned by legal acrobatics conducted as if the law could be a "means" of a group to support their interests. The legal culture of the leaders has turned into a culture of conspiracy and shameless culture so that anecdotes arise: The blunted law up and sharp down. The fundamental question is what causes a person who is clever, wealthy and of high rank to be not afraid of breaking the law?

I assume that various legal issues come from ignorance and reluctance. The general public, including legal scholars, holds that the matters of quality are the problems of economists, technocrats or businessmen. Those are the quality of goods, the quality of performance, and the quality of the product. Thus, people who have professions outside the field of economics as if there is no need to learn the quality of science. That is why the development of human resources through the quality system does not develop quickly.

This essay argues that quality science should be applied by all professions, including legal profession. Legal profession is a profession that provides services to the public. The law is neutral; it depends on the law enforcement. In the case of law enforcers with good intentions, law can bring benefit. On the contrary, if law enforcement is not good or selfish, then law is used to suppress other party.

In economics, quality is defined as the appropriateness between consumer expectations and what is obtained from the producers, for example: cars made by European countries are very good from various aspects, but they are not sold in Indonesia because they are not affordable to Indonesians and the size dan model does not fit Indonesian body posture. In contrast to Japanese cars, which are cheap, small, and economical, they in fact sell well because they are affordable to Indonesians and the size and model fit Indonesian body posture.

The quality of the law is defined as the suitability between what is supposed or often referred to in German as "das sollen" with what is happening in reality or often called "das sein". Das sollen is legislation, while das sein is standardization of law quality. The degree of conformity between "das sollen" and "das sein" is defined as legal effectiveness.

The degree of conformity between "das sollen" and "das sein" is interpreted as legal effectiveness. The term quality science that is used in this essay refers entirely to two quality science figures, named Juran and Deming who have written many books on Quality Sciences and Quality Assurance System. 


\section{LEgAl QUALITY AUdiT PARAMETERS}

Quality science underlies the paradigm of business ethics, and in current global era, Indonesian businesspeople will soon be replaced by businesspeople from developed countries because they have long under laid their business ethics with quality science. The business world needs to be implemented with genuine business ethics or economic ethics by economic actors, entrepreneurs and society in general [1].

The formulation of the meaning of 'quality' is not easy, and to reach an agreement on the meaning of quality is also not simple because in the dictionary there are dozens of definitions. There is no precise definition, but there is a widely accepted one: quality is a suitability to use; this definition does not have the depth to act. Quality is the suitability between the user's wishes of goods or services and the provider of goods or services [2]. This compliance is based on the two main pillars of quality, which are:

1. Defect free, which means that the service provider should make every effort to do good, avoid defects, and be professional.

2. Service user satisfaction, which means that the service user or goods feel satisfied because the suitability of the goods or services obtained are free from defects.

Is the law enforcement a product or service that meets or exceeds the expectations of the service user? This question is difficult to answer. Therefore, we should pay attention to the quality elements that exist, which are the elements of quality, and they are [3]:

1. Efforts to match or exceed customer expectations;

2. Inclusive services; and

3. Ever-changing condition

If civil law subjects merely perform normative promises or simply implement signed commitments or agreements, this means that the subjects of civil law have not exercised full quality because the satisfaction felt by the service user is low satisfaction or basic satisfaction.

Similarly, if law enforcers implement the law in accordance with applicable regulatory mechanisms or simply implement Standard Operating Standards (SOS) then the results of Legal Quality Audit are low. For example, if the Panel of Judges in the District Court drops the Court's ruling in six months, which is in accordance with its SOS, then the quality of the audit result is low.

Guidelines on "The audit of legal quality" should be structured in written form which is called "Quality Management Manual". Information on the quality management manual affects the way everyone in the organization performs their tasks. This is not a public relations practice or something to show on a visit but rather a working document relevant to its users [4].

In the field of economics is known a term called financial audit, and there are internal audit and external audit conducted by the person doing the audit work, also known as the auditor. The job of an economic audit is to measure the suitability between the plan and its implementation, and there will be sanction if the plan is not reflected on the implementation.

The word "audit" (examination) raises issues because it is considered as a quantitative measure, like financial examination. At the present level of knowledge, we do not have enough understanding to pinpoint problems appropriately, especially to measure all their outputs. Audits are used because they relate to objectivity, comprehensive analysis, regularity and reporting [5]. Practitioners and legal academics largely disapprove of, or even have allergies to quantitative audits of law enforcement, while qualitative auditing is difficult. In legal jurisprudence, the terminology of legal auditing is not commonly used. The closest legal terminology used is Materiel Test of the legislation.

The Material Test is a test activity against a rule with higher regulations. Today, Materiel Test may be submitted to the Constitutional Court, and is only done in a limited testing legislation with the benchmarks of Articles 1945 Fourth Amendment. The weakness of the current Materiel Test system is that there is no forum or institution authorized to conduct a Material Test of a regulation that level under the Act. This essay assumes that this is a legal vacuum in the Material Test and this condition has caused many legal problems at present time.

In terms of legal audit, this essay proposes a new concept of 'Legal Quality Audit'. It is generally an integrated form of quality science and legal audit, with the quality of the law that is being audited. The quality audit should put forward the two pillars of law, which are: moral and human reason. In Western law, a theory argued that the use of the death penalty is contrary to Islamic law rights. Islamic law applies death penalty based on the command of God as the owner of life as stated in the Quran and Hadith, and it is precisely because of this reason that the use of the death penalty in the Islamic perspective aims to ensure the survival of the human [6].

In the framework of the Quality of Legal Audit, both pillars of quality are described in the characteristic (benchmark) of the quality audit of the law, including:

a. Quality of product: the quality of legal products or products of legal services with symbols (q). As an illustration, the quality of products in the form of services from the legislators are said to be of quality if the rules that have been made and ratified are not there, or there are only few who protest or urge it to be revoked so that the regulation is valid for long periods of time. 
Another illustration is the quality of products in the form of judicial services in the Court in which very few or even no one filed a legal action by either party or both parties to a higher court.

b. Minimum cost: minimum cost incurred, with symbol $€$. Government prohibition to Civil Servants not to conduct meetings in hotels is a government policy that is already a quality insight because it will reduce the cost of meetings. Lawmakers and members of the House of Representatives will save a high cost if the act of drafting a regulation is implemented at the office, not at a hotel.

c. Availability/Access (Delivery): easy access to easy, effective and efficient service, with symbol (d). Public access to information and legal services is one of the indicators of quality. This access problem becomes an important issue because Indonesia is a vast archipelagic country.

d. Security (safety): legal products should be safe, and does not cause misery, with symbol (s). The law should be neutral, not made for the benefit of the Law Maker or a group order but should serve to provide protection to all elements of the country, including citizens.

e. Good service (mores): mutual respect between service providers and service providers with service users, with symbol (m). In legal theory, it does not discuss about the friendliness of law enforcers in carrying out their duties. The police, prosecutors, judges, lawyers and public officials often pay little attention to friendly service to the effect that the law is cruel or unfriendly. In lectures in law faculty, there needs to be a discussion about 'quality culture' with friendly service as one of its elements.

f. Systematic: system is created, with symbol (s). this is relevant to a course on Interstitial Law of Indonesia at the Faculty of Law Universitas Padjadjaran. It has to do with 'rule of law', which is interpreted here as is 'legal system'. Thus, legal system is familiar to students and legal scholars.

g. Following the development/trend of society (environment), with symbol $€$. The Legal System of national law should follow the development of global law. Therefore, the Indonesian government should actively participate in international meetings so that legal reform can be done continuously. Thus, theoretically, to produce qualified and aspirational representatives of the people, one of them should be chosen by a good mechanism with strict conditions [7].

The audit of law, in my perception, differs from the test of matter embodied in our positive law, namely:

a. Legal audits can be conducted at every level of regulations ranging from the Constitution to the Regional Regulations, while Material Test can only be done against the law-shaped regulations. The legal audit of the Constitution can be tested by measuring the philosophy of state/nation, which in this case is Pancasila. Legal audit is static and dynamic, while Material Test is static. Static in the sense of test against legislation or, in other words is called normative test. In this normative audit, a regulation is tested with higher regulations, with higher regulation provisions considered as true. The dynamic is due to the testing of the application of a rule, called Audit Implementation of law. In the audit of these applicable laws, legal facts or application of law are examined, while the test norms are the regulations applied. The trial process in the Court is essentially an implementation audit of the law.

b. Judicial audit, in my understanding, can be done by government agencies and private institutions, while test of material can only be done by the Constitutional Court through a trial conducted.

\section{LEGAL QUALITY CULTURE}

Quality science is a science that is unheard of by the law because it is within the business domain, especially management. When the jurists were invited to have a discussion regarding this matter, it did not get a positive response. I believe that ignorance and reluctance of legal experts about quality science is one of the sources of the problem of the injustice and uncertainty of the application of law in Indonesia. The basic question that I was asking is: 'How can the legal norms and their application be of high quality, if the law does not know about the quality of law'. The smaller the degree of quality, the greater the arrogance of the law, and the degree of law enforcement arrogance can be minimized.

In order to overcome these problems, quality science should be socialized as early as possible in formal education starting from Early Childhood Education to higher education. Legal education is an education that should receive a portion of the socialization of the quality of law. Therefore, it should be included in the legal faculty curriculum independently and not part of character education or legal theory.

An early integration of quality science is very important to unite the essence of quality with the mindset of the society, who will personally become the paradigm of Indonesian society. The integration of quality science through formal education and daily behavior on an on-going, planned, systemic and consistent basis will bring about a quality culture. Quality culture is the main element that can improve the civilization of Indonesian nation. With quality culture, the achievement of the second Precepts of Pancasila which reads: 'Just and civilized humanity' can be accelerated.

The implementation of a separate way of thinking in the former system, which is consequently the application of quality systems rather than improving civilization and performance, makes it rather a burden and it can reduce performance. For example, the 
application of ISO 9000 (as one of the quality system products), with the slogan 'Write what you will do, and do what you write' causes businesspeople to do paperwork as additional and separate work.

For the law, the inclusion of the quality of law science into normative legal system and implementation of law system since early semester of law faculty facilitates the formation of thought patterns and patterns of student behavior based on quality. On an on-going basis, this condition will shape the culture of law quality.

\section{CONTRIBUtion OF LEGAl QuALity Audit IN ECONOMIC LEGAL DEVELOPMENT}

Economic Law, in my understanding, is not solely Law governing economic activity, because if it is so, Economic Law is mono disciplinary. Economic Law is the Law of the result of integration of legal discipline with the discipline of economics and is therefore multidisciplinary. The real form of economic law is Business Law. Indeed, all courses in the Faculty of Economics and the Faculty of Law are elements of the formation of Economic Law and Business Law.

\section{A. Development of the Law of Agreement in the Era of Regionalization}

Regionalization of economy is inevitable, since in 2016 the era of regionalization of the ASEAN Economic Community started. Regionalization is basically a regime of economic unification in certain regions, such as ASEAN. Cross-border countries of goods and services will occur instantly. Legal and business certainties are advantages for preparing countries, and they otherwise become a risk if it does not prepare itself unintelligently.

As most people know, contract law is the most important law in business activity. It is precisely in this most important law that Indonesia does not have a national agreement law. We take it for granted to use Book III of Civil Code which is a translation of Burgerlijke Wetboek colonial era. The choice of law and forum choice is an important clause in an international agreement. It seems that Indonesian law and justice forums have not been that interesting to be elected while our judicial forum has not been an option due to its long and frequent fraud. The legal consequence of such non-electability is the election of laws and forums of other countries. This condition certainly does not benefit Indonesian business players in global competition.

The development of economic law, especially the law of the treaty is urgent. The development in a regional or global atmosphere can be done with harmonization of contract law. But with the validity of the MEA, the harmonization of contract law is not ideal anymore because it takes a long time. The only way is with the integration of the legal quality system because the quality of science is universal. As an initial step, it is necessary to perform quality legal audit both in a normative and applicable manner.

The legal development solution of the Treaty based on the quality system of the law is the integration of the quality system into the lex contractus, particularly the clause set forth in the agreement. With the characteristic of the quality of the product, the agreement clause is made as complete as possible so that the minimum depends on The Contract Law. The reliability of the product here is in the sense that the completeness of the clause required by the parties signing the agreement materializes as an accidental element.

Lex contractus in the Civil Code is based on freedom of contract, in which it provides an opportunity for the party making the agreement to include what the parties of different nations or states wish to pursue in the agreement clause. As we all know that in a society whose thinking is civilized, the quality of law unifies different legal systems in harmony of law. Integrating the quality of law science into lex contractus is in accordance with the characteristics of legal quality of science that is minimalist in cost.

The development of Lex contractus in the development of the Law of the Covenant in accordance with other legal quality science characteristics is the environmental symbol $€$, that is, to adapt to the environment, which in this case the MEA, as a regional business environment. With further arrangement of agreements in the contractual clauses, the parties to the agreement minimize the difference in the interpretation and execution of the agreement.

\section{B. Legal Human Resource Development}

The application of a culture of legal quality, related to human resource development is the application of moral quality characteristics, which in this case is defined as the hospitality of law enforcement and legal servants. As we all know, the understanding of the normative system of our law enforcers is adequate, and even the application of law is capable. The system quality of law in this case is not just to discuss how professional law enforcement and legal servants are, but also 'hospitality' in the ministry.

Hospitality involves sincerity, honesty, unpretentiousness, smile, disdain-free and discrimination-free attitudes, and convenience to those who are served. Hospitality is the added value of discipline and accuracy in the ministry. Friendliness prevents law enforcers and legal servants from being irritable, arrogant, judgmental, and cruel over others.

In relation to the development of economic law in Indonesia, the assessment and application of these hospitality characteristics is essential in services related to public administration services, including services such as: licensing, taxes, justice, consultancy, notarization and procurement. With this hospitality applied, there will be less legal smuggling efforts and 
reluctance to deal with law enforcement and service. In the long run, the implementation of hospitality as a legal culture will make the perpetrators of domestic economy and global economic actors comfortable and content to invest in Indonesia.

\section{Reachability of the Rule}

The history of legal drafting is usually done in a long time, such as the formation of the Civil Code (Burgerlijke Wetboek). This preparation obviously required a big budget. Audit law quality instructs that the legal costs should be minimally possible. Legal costs include the cost of preparation, the cost of authorization, the cost of socialization, and the cost of repair.

The magnitude of these legal costs needs to be balanced with the enforceability of the regulation. The longer the enactment of a regulation, the lesser legal cost it will require. Thus, the necessary human resources in addition to knowing the substance of the rules are prepared, and the techniques of regulation are also a very necessary ability to look to the future (futuristic) by using futurology.

Until now futurology has not been taught as a course in the faculty of law, so most of the drafting of legislation is mastered less. As a result, many regulations are continuously changed, and there are even regulations that require retraction in a short period of time.

In the development of economic law, the objective of this legislation is very important because it involves legal and business certainty. Regularly changing business plans and strategies often requires business actors, and obviously, for that it requires unnecessary cost. Legal uncertainty resulting in business uncertainty should be kept to a minimum, because if it is too late to anticipate, it can potentially become a 'country barrier'.

In regional and global businesses, legal and business certainties are one factor for foreign investors to decide whether to choose to invest in Indonesia. For this, legal comparison with other countries is required, at least with the ASEAN countries on the reach of legislation.

\section{Prevention of Corruption}

A criminal act of corruption is a severe legal act according to the quality of law because it is not in accordance with the two main pillars of the quality of law science, namely: free of disability and user satisfaction services. Corruption falls into the criteria of free of defects because the perpetrators do not run their legal obligations properly, that is, the law. The neglect of the legal obligations of these corruptors is because their actions are influenced by other parties, carried out jointly with other actors. This is often called 'congregational corruption'.
This act of corruption obviously only brings profit to the perpetrators of corruption, or the parties who give gifts or bribe the corruptors. Such actions are detrimental to society and the state. Communities are disadvantaged because the tax paid is not used for development and public interest. On the other hand, the state is disadvantaged because the state finances are used for personal or group interests.

With the understanding and application of the 'defect-free principle', it is expected that corruption can be prevented as early as possible through education from the lowest level of formal education in Early Childhood Education to the highest level of formal education in university. These defect-free principles should be conducted in education sector through integration in the curriculum, such as Citizenship Education, Religion, Charisma, Scout Education, Business Ethics, Professional Ethics, and codes of conduct.

Defect-free integration is not enough because it does not know, understand, let alone apply the quality characteristics. Therefore, the quality science, and how the simulation of various models of quality is applied needs to be integrated in the curriculum as subjects or subjects is Quality, while for the Faculty of Law is the Quality of Law.

\section{E. Acceleration of the Settlement of Disputes through Peace in Civil Proceedings}

The failure of the previously mentioned bureaucratic reforms proves that the government's strategy in improving judicial bureaucracy is different from the strategy proposed in this essay. The government improves the performance of the judiciary at the highest level, the Supreme Court. Based on the science of law quality, this essay argues that reform of the law enforcement bureaucracy should be conducted at the lowest level, directly serving the community, namely first-level courts (district courts, religious courts, military tribunals, state administrative courts, and commercial courts); Police, state prosecutors and the Corruption Eradication Commission.

It can be conveyed that due to the legal effort, the legal action of the parties to the dispute or litigation is to file an examination of the application of law in the first level of court. Based on observations over the years, I believe that most cases are decided in court as first attempt on the second level law, that is the appellate court, and the cassation level is the Supreme Court. In practice, many parties are dissatisfied with the decision of the Supreme Court, but they are still making legal review efforts.

The problem of legal effort is a matter of serious legal quality, because it involves two main quality pillars, namely defect free and user service satisfaction. Legal efforts indicate dissatisfaction of one of the parties, so they request for a higher court to re-examine the application of law. in my opinion, the dissatisfaction of one party can occur because the 
performance of law enforcement officers 'contained defects' or the performance of the apparatus is qualified, but one party does not want to accept defeat that harms him.

The application of legal quality will be successful if all stakeholders know, understand and implement the quality of law. Continuous application of legal quality will shape the culture of legal quality. In the case of a culture of legal quality, the legal effort has been reduced drastically. As a result, law delinquent cases in the High Court or Supreme Court will be reduced drastically.

The impact of applying a quality legal audit to the first jurisdiction is to accelerate the settlement of the dispute because it is enough with one stage of the trial only. For civil proceedings, it is necessary to develop a peace effort which is the first stage of the initial trial. The peace efforts in this trial differ from the one outside the session, because the outcome of the peace, the peace agreement, is part of a judge's verdict which has the power, the exact law.

On the basis of the quality of law, peace in court meets all quality legal criteria (Quality/Q): product reliability (quality of product/q), minimum cost (c), availability of access (delivery/d), security, hospitality (mores/m), systemic (systemic/s2) and following developments (environmental/e). Therefore, it should be prepared by the reconciliation judges who already have a legal quality certification.

\section{F. Simplification of Law Enforcement Institutions}

The application of quality law science leads to a decrease in the legal remedies of the court of first instance to the level of appeal, and from appeal to appeal. Such conditions accelerate the travel time required to settle disputes in court, which means cost savings or in the language of quality is a minimal cost (cost).

Improving the quality of first-level law enforcement is not an easy job for the government, since it requires quality cost. However, the quality cost will be replaced by a reduced legal cost that is not comparable because, in addition to reduced legal costs at the appeal and cassation level, there is no need for other law enforcement agencies.

In relation to the development of the Economic Law, the centralization of the government's attention to apply a culture of legal quality to the first level law enforcement agencies will result in enormous savings, namely the legal costs of routine fees of the commissions such as: the Corruption Eradication Commission, the Prosecutorial Commission, the National Police Commission, Judicial Commission and Ombudsman. The commissions are formed because the quality of the culture has not yet been implemented, resulting in the discontent of justice seekers caused by the non-realization of defect free in all stages of law enforcement.

\section{CONCLUSION}

To improve the quality of law enforcement, both in the preparation of regulations, supervision, and law enforcement, it is time to do a quality audit law. The quality of law is the basis for the quality audit of the law. Thus, the quality of law science should be a new paradigm of law stakeholders. In the quality system of law, the implementation of legal quality cannot only be done by law enforcers, but also all members of society so that the realization of Quality Culture Law can be achieved.

With Legal Quality Audit, law makers and law enforcement are encouraged to work on their legal obligations. Quality science, law quality and quality law are included in the Faculty of Law curriculum so that the cultural paradigm of the quality of law can be embedded in the students so they could later be a driver of acceleration to the realization of a quality culture. In addition, the state should provide incentive funds to quality stakeholders who have carried out their obligations based on quality science.

\section{REFERENCES}

[1] Supanto, "Kejahatan Ekonomi Global dan Kebijakan Hukum Pidana," Bandung: PT. Alumni, 2010, pp.14.

[2] J. M. Juran, "Juran on Leadership for Quality," Jakarta: Pustaka Binaman Pressindo, 1995, pp.16-17.

[3] Fandy Tjiptono and Anastasia Diana, "Total Quality Management," Bandung: Andi Offset, 1995, pp.2-3.

[4] Jenny Waller, "The Quality Management Manual: How to Write and Develop a Successful Manual for Quality Management Systems," Jakarta: Pustaka Binaman Pressindo, 1994, pp.6.

[5] John Humble, "Social Responsibility Audit A Management Tool for Survival," Jakarta: Lembaga Pendidikan dan Pembinaan Manajemen, 1981, pp.43-44.

[6] Sigid Suseno, "Urgensi dan Dasar Penggunaan Pidana Mati dalam Hukum Pidana Indonesia," Padjadjaran Jurnal Ilmu Hukum (Journal of Law) Bandung, vol. 04, no. 01, 2008, pp.48.

[7] Hernandi Affandi, "Menuju Lembaga Perwakilan Berkualitas dan Aspiratif: Beberapa Catatan terhadap Undang-Undang Nomor 10 Tahun 2008 tentang Pemilihan Umum Anggota DPR, DPD, dan DPRD Padjadjaran Jurnal Ilmu Hukum (Journal of Law) Bandung, vol. 04, no. 02, 2008, p.11. 